\title{
Alteridad y mímesis del pirata en la épica colonial ${ }^{7}$ \\ Pirate Alterity and Mimesis in Colonial Epic Poetry
}

\section{Javier de Navascués}

Universidad de Navarra

ESPAÑA

jnavascu@unav.es

[Hipogrifo, (issn: 2328-1308), 4.1, 2016, pp. 43-63]

Recibido: 19-01-2016 / Aceptado: 07-03-2016

DOI: http://dx.doi.org/10.13035/H.2016.04.01.04

Resumen. Se estudia la representación del pirata en una serie de poemas épicos en el final del siglo XVI y comienzos del siglo XVII. A partir de textos de Juan de Miramontes, Pedro de Oña, Martín del Barco Centenera y Juan de Castellanos, entre otros, se comprueba la ambigua imagen del enemigo inglés. De un lado, los textos épicos ignoran las importantes diferencias entre corsarios y piratas, ya que la guerra de corso había sido aceptada legalmente por todas las naciones europeas, incluida España. Además, el pirata es llamado siempre «luterano», revelándose así su absoluta otredad respecto del modelo católico. Por otra parte, los textos épicos proponen una pintura elogiosa del enemigo a partir de la imitación de los valores aceptados por la sociedad colonial. La relación entre el héroe español y el corsario se manifiesta entonces no en un sentido vertical, como podría suceder entre el sujeto colonizador y el colonizado, sino en un plano de rivalidad.

Palabras clave. Épica colonial, piratería, Juan de Miramontes, Barco Centenera, Juan de Castellanos.

Abstract. Pirate representation is studied in a series of Epic poems in the late sixteenth century and early seventeenth century. The ambiguous image of the English enemy is read in texts by Juan de Miramontes, Pedro de Oña, Martín del Barco Centenera and Juan de Castellanos, among others. On the one hand, Colonial Epic ignores some important differences between privateers and pirates since the privateering had been legally accepted by all European nations, including Spain.

1. El presente trabajo se enmarca dentro del proyecto Proyecto I+D del Ministerio de Economía y Competitividad En los bordes del archivo, l: escrituras periféricas en los virreinatos de Indias (FFI201563878-C2-1-P). 
Besides, Pirate is always called «Lutheran» and revealing its absolute otherness with respect to the Catholic model. On the other hand, it proposes a laudatory epics enemy painting from the imitation of the values accepted by the colonial society. The relationship between the Spanish hero and the privateer is represented not in a vertical direction, as could happen between colonizer and colonized subject, but on a level of rivalry.

Keywords. Colonial Epic, Piracy, Juan de Miramontes, Barco Centenera, Juan de Castellanos.

A partir de 1585 la épica en América comienza a dar cuenta de nuevos conflictos producidos tras la consolidación de la Conquista. Si La Araucana ya había mostrado las dificultades de un ejército ante la resistencia indígena, ahora el fenómeno de la piratería o la guerra de corso practicado por las potencias rivales europeas, planteaba un nuevo frente militar y literario. Entre los poemas publicados o escritos en la última década del siglo XVI y los primeros compases del XVII, se encuentran algunos que tienen a la lucha contra el corsario como tema principal o le dan cumplido espacio (Elegías de varones ilustres, Armas antárticas, Espejo de paciencia). Otros poemas, tras haberse extendido en combates con los indígenas, se cierran con la llegada de los piratas: La Argentina y conquista del Río de la Plata (1602) de Martín del Barco Centenera, Arauco domado (1596) de Pedro de Oña o La guerra de Chile (h. 1610) de autor anónimo. En las líneas que siguen abordaré el tratamiento que algunos poetas de la Colonia hacen de la piratería tras la singladura de Francis Drake (1578-1579) por las costas del Pacífico que tanto conmovió a la sociedad del virreinato del Perú. Este tipo de expediciones puso de relieve la debilidad de las defensas españolas, quienes se enfrentaban en América por primera vez a un enemigo en igualdad de condiciones en el plano de la tecnología militar. La lectura de los poemas épicos que tocaron el tema subraya la mirada de temor y admiración que la clase letrada colonial sintió por el pirata, visto como «bárbaro» y «luterano», a la vez que caballeresco y audaz navegante, único capaz de emular a Magallanes y otros héroes del imaginario imperial español.

\section{REPRESENTACIONES DE UN MUNDO FRÁGIL}

El tema de la piratería en la épica colonial permite descubrir una sociedad que empezaba a manifestar ciertas tensiones internas en la segunda mitad del siglo $\mathrm{XVI}$. No es casual que algunos poemas den cuenta de las simpatías, cuando no de alianzas, que los negros cimarrones o los indios pudieron establecer con los piratas a los que veían como posibles libertadores del yugo español. Armas antárticas (1609), de Juan de Miramontes y Zuázola, refiere el acuerdo entre los corsarios ingleses de John Oxenham y un grupo de negros fugitivos con el fin de asolar Panamá. Otro ejemplo: La guerra de Chile pinta en sus últimos cantos la llegada a la isla de Chiloé de la expedición holandesa al mando de Baltazar de Cordes. Los forasteros entablan amistad con los indígenas y estos ven la oportunidad de librarse 
de los españoles con el auxilio de los recién llegados². En realidad, el elemento perturbador del pirata lleva a que afloren temores en el discurso colonial que, de otra manera, no saldrían. Un miedo recurrente en crónicas y poemas es que las clases subalternas, indios y esclavos, ante la proximidad del enemigo europeo, boicoteen el sistema desde dentro. Por ejemplo, que le quiten los frenos a los caballos, como dicen Barco Centenera o Castellanos que hacen los esclavos negros a sus amos ${ }^{3}$.

Los piratas son la ocasión para que la épica nos introduzca en un escenario menos sólido de lo que la propaganda oficial podría anunciar. Algunos poemas, como las Elegías de Juan de Castellanos o la Argentina de Barco Centenera, no rehúyen informar de deserciones, cobardías o tratos ilícitos por parte de los españoles con Ios corsarios. La Elegía XIV de Castellanos cuenta, por ejemplo, la traición de Diego Pérez que se encontraba en connivencia con el pirata francés Jacques Sorel. Tal y como ha estudiado Marrero-Fente, la conclusión del episodio se remata con la crítica al contrabando por parte de los españoles y su abandono de los ideales caballerescos ${ }^{4}$. Otras veces la imprudencia es la que conduce a una emboscada fatal, como la que comete García Oñez de Loyola en el desastre de Curalaba (La guerra de Chile) o a la que lleva a Juan de Garay a la muerte (Argentina). Un mundo frágil: este es el paisaje de la América dominada de forma precaria por España y sometida a una permanente amenaza exterior e interior. Indios, cimarrones y corsarios se enfrentan al poder hispano en numerosas ocasiones. El abandono de un ingrediente básico del género, como es el ejercicio de las armas, se erige en un motivo recurrente en pasajes de Armas antárticas, Elegías de varones ilustres, Argentina y la conquista del Río de la Plata, La guerra de Chile o el Purén indómito. La narración de la desidia de los conquistadores expone amenazas a la continuidad del sistema. En efecto, a las tensiones externas se unen de vez en cuando las propias de la sociedad colonial, convulsionada por las actitudes de muchos de sus miembros más relevantes. La indolencia, la pereza o la soberbia de los dominadores se esconden detrás de la inestabilidad de su poder. No es casual que los desastres naturales (terremotos, tempestades) o las derrotas militares se atribuyan a las debilidades y pecados de gobernantes, encomenderos o simples colonos ${ }^{5}$. La épica indiana de fines del siglo XVI y comienzos del XVII desnuda los miedos de una clase dirigente que elabora una imagen del enemigo y construye sus propios argumentos de legitimación. En ocasiones, incluso, denuncia desvíos del proyecto colonial; en otras, oculta tensiones entre individuos o entre las distintas instancias de poder ${ }^{6}$.

2. La última octava del libro expone en boca de un indio chilote el estado de dejadez y apatía con que viven los españoles: «Seguros, sin mirar en esta estancia, / qué cerca está el peligro del olvido, / por muros tienen sola su arrogancia, / gobiérnalos el padre del perdido; / huyendo anda de allí la vigilancia / y el recato también de allí se ha huido; / la blanda paz sus armas afemina / y el tiempo con su orín se las orina», Anónimo, La guerra de Chile, p. 459.

3. Barco Centenera, Argentina y conquista del Río de la Plata, p. 326

4. Marrero-Fente, 2014, p. 7.

5. En el Purén indómito (1603?), por ejemplo, los exitosos levantamientos araucanos se explican por la indolencia y los abusos de los españoles en Chile. Ver Fernández, 1984, especialmente pp. 113-114.

6. Con la llegada a Panamá del corsario John Oxenham («Oxnán») hubo numerosas tensiones entre la Audiencia y el Virreinato del Perú acerca de cómo organizar la defensa y de cuáles eran los atributos ju- 
La escritura de epopeyas por parte de soldados, letrados y eclesiásticos bajo el mecenazgo de algún poderoso no sólo expuso el rostro triunfal de los conquistadores. Al enfrentarse con los protestantes enemigos en Europa, más bien se reproduce la imagen de una comunidad cuyo heroísmo se sostiene por la defensa de la fe católica que legitimaría al imperio. Con el surgimiento de la piratería, la acción pasa a ser inevitablemente defensiva. Pero hay más. La lectura hoy de los poemas épicos coloniales nos sugiere los costurones de una sociedad en crisis, una sociedad necesitada de justificarse ante situaciones que la cuestionan. La piratería puso de relieve flaquezas externas e internas que de otro modo no hubieran sido visibles. De ahí que podamos juzgar la épica desde un trasfondo de preocupación «por el debate político y moral sobre el buen gobierno en la América española»? El discurso de estos textos es menos monolítico de lo que pudiera creerse. Según de cuáles hablemos hay espacio para cuestionarse los cimientos sobre los que se sostiene el edificio colonial. Así ocurre con las respuestas a la existencia de enemigos externos a los que forzosamente se les debe presentar con alguna ambigüedad. Frente a la indolencia con que a veces se retratan ciertas actitudes de pobladores españoles o criollos (en Barco Centenera, en Juan de Castellanos, en Arias de Saavedra), los piratas son gente audaz y convencida de su propio valer, aunque estén inficionados de herejía.

\section{PIRATAS Y CORSARIOS}

En el Canto III de Armas antárticas Draque presenta ante Isabel I de Inglaterra su ambicioso plan de saqueo de las costas del Pacífico ${ }^{8}$. El marino inglés se dirige a su reina de la siguiente manera: «Que como el arte de la mar profeso / y en ella tu servicio real milito, / en cartas cosmográficas tengo espreso / todo el viaje, del derrotero escrito» ${ }^{9}$. El sujeto se presenta entonces como un navegante que rinde vasallaje a su señor natural a través de la llamada guerra de corso. Su iniciativa pasa por la aprobación de un poder legalmente constituido. Por eso sus intenciones son honorables según las palabras del personaje. La asociación de este tipo de actividades con la delincuencia podía no estar nada clara. Corso procede del latín cursus, 'carrera', y, según el Diccionario de Corominas, corsario fue en el siglo XIV 'aquel navío ligero que corre los mares'. El significado de corsario (o más claramente privateer en inglés), tal y como ha pasado a las distintas lenguas occidentales, incluida la española, designa a un marino y a su embarcación privada, que tiene la autorización de su gobierno para atacar a barcos de otras naciones enemigas del Estado, principalmente en tiempos de guerra.

Sin embargo, la distinción entre corsario y pirata no era tan diáfana para los letrados españoles del siglo XVI. Según Covarrubias una y otra voz eran sinóni-

\footnotetext{
risdiccionales de cada uno (Nakashima, 2014, p. 312). El poema Armas antárticas, que dedica al suceso varios cantos, ofrece una versión de unánime coordinación entre los españoles.

7. Segas, 2015, p. 4.

8. La mayor parte de los textos españoles emplean la forma «Draque». Utilizaremos esta grafía para referirnos en exclusiva al personaje literario, mientras que emplearemos Drake para el personaje histórico. 9. Miramontes, 2006, p. 223
} 
mas. Pirata sería 'el cosario que roba por la mar, latine pirata'10. Los textos literarios tampoco separan demasiado los significados de una y otra palabra, más bien las consideran sinónimas. Bernardo de Balbuena, por ejemplo, escribe:
Allí por lances y peligros varios
La mar nos despeñó y allí perdimos
Nuestro bajel y en otro de cosarios
Que en el puerto hallamos nos metimos:
Andaban en sus robos ordinarios
De la herviente costa a los arrimos
Cien piratas a cuenta de un gigante,
Gran capitán de Creta y rey de Jante ${ }^{11}$.

Pedro de Oña no considera el contexto bélico entre Inglaterra y España para suavizar el tratamiento de pirata como término equivalente a corsario. Cuando tiene que presentar a Richard Hawkins (Aquines en su poema), quien trató de saquear las costas de lo que hoy es Ecuador en 1594 durante la guerra anglo-española (1585-1604), iguala los dos calificativos sin precisar ningún otro matiz ${ }^{12}$. Las razones esgrimidas por los españoles para declarar piratas a los ingleses, se basaban en el tratado de Tordesillas, firmado bilateralmente con Portugal. Las dos potencias ibéricas intentaron aplicarlo a toda la Cristiandad. De acuerdo con esta perspectiva interesada, la ruptura de un monopolio comercial sancionado nada menos que por la autoridad papal, podía ser vista como una violación injustificable. El tratado se había sometido a la autoridad máxima desde el punto de vista católico. De ahí que los ataques a sus intereses, incluso aunque se estuviera en tiempos de guerra, carecían de justificación legal y moral. Por supuesto, para los ingleses, que no aceptaban el tratado por la misma razón que los españoles creían en él, la distinción entre corsario y pirata en América era decisiva: sus acciones eran vistas por ellos como legales, ya que estaban intentando una serie de transacciones al margen de una ley no reconocida por lo que hoy sería el Derecho internacional ${ }^{13}$.

En la épica colonial ser nombrado pirata y/o corsario expresa, desde el punto de vista hispano, un desplazamiento al otro lado de la legalidad sin remisión. Aquí conviene subrayar que los textos épicos ignoran las importantes diferencias entre corsarios y piratas. En realidad, el corso era una modalidad de guerra practicada por todas las potencias europeas, incluida España, a lo largo de los siglos anteriores y en los venideros. Algunos estados católicos como Malta fomentaban el corso,

10. Covarrubias, Tesoro de la lengua castellana o española, p. 620.

11. Balbuena, El Bernardo, o Victoria de Roncesvalles, p. 175.

12. «...de suerte que no entrase cada día / esento por sus puertos el cosario, / haciendo en los que estaban sin defensa / un daño, cada vez, sin recompensa [...] Así el audaz pirata se decía / Y Aquines por blasón, de clara gente» (Oña, Arauco domado, p. 497).

13. Los españoles acusaron también a los ingleses de no respetar las treguas, igual que el monopolio. Pero estos últimos se escudaban también en la doctrina de que «no había paz más allá de la línea». Este principio paradójicamente lo crearon los mismos diplomáticos españoles en un acuerdo verbal de la Paz de Cateau Cambresis (1559), por el cual se podían hundir todos aquellos buques franceses que entrasen en el «hemisferio español» (ver Otero Lana, 1999, p. 35) 
y no siempre contra países islámicos ${ }^{14}$. En cambio, la piratería, que no la guerra de corso, era siempre ilegal e inmune a los tratados de paz. Al estar al margen de cualquier requisito jurídico, podía ejercerse de forma esporádica, incluso, y hasta improvisada, y esto valía no sólo para las naciones enemigas de España o Portugal. Aunque los portugueses no pasaban por ser una nación pirática, uno de sus héroes indiscutidos, Vasco de Gama, la ejerció de forma tan desembozada que Camoens la exalta en sus Lusíadas (2,68-69). En efecto, después de saquear Mozambique y mientras está recorriendo el trecho que va de Mombasa a Malindi, el descubridor de la India aborda un barco musulmán. Su victoria lo convierte en un héroe, desde el lado cristiano, pero no es difícil suponer que sería visto como un pirata por los musulmanes ${ }^{15}$. Por lo demás, esta clase de acciones no sólo las ejercieron los lusitanos, sino que muchos otros actos semejantes a cargo de españoles podrían mencionarse antes, durante y después de la segunda mitad del siglo XVI, cuando Drake, Cavendish y los Hawkins transitaban por el Caribe y el Pacífico sur ${ }^{16}$. Lo que Camoens cuenta de Vasco de Gama no es, por tanto, un caso aislado, aunque tiene especial interés debido a la trascendencia del protagonista, que se hace merecedor de una epopeya nacional. Por tanto, en el discurso épico ibérico, la piratería o el corso sólo serían nombrables como tales cuando la ejerce el otro (el musulmán, el luterano), pero no cuando es un acto cometido por un católico. La justificación implícita era que las naciones católicas podrían considerar que las diferencias religiosas eran suficientemente importantes como para considerar que los herejes o los infieles se convertían automáticamente en enemigos de Estado por razones de creencia.

La cuestión desde el otro lado era también complicada. Los ingleses, ante la falta de una armada fuerte como la española a mediados del siglo XVI, combinaban capitales privados y de la corona a fin de proyectar expediciones con ánimo mercantil en las que se dividían los ingresos según lo acordado ${ }^{17}$. En ocasiones, saltándose las leyes del monopolio imperial, los ingleses, como los corsarios de otras naciones europeas, comerciaban con los colonos españoles en América. De hecho, las mismas autoridades locales propiciaban estos encuentros, tal y como denunciaba un documento anónimo de $1579^{18}$, el «Advertimiento cerca de la contratación que tienen los cossarios en algunas partes de Indias». De acuerdo con la coyuntura, pues, el corsario podía negociar o tener una actitud hostil; podía verse a sí mismo como un navegante que luchaba sólo por sus intereses mercantiles o los

\footnotetext{
14. Sobre el corso en España en los siglos XVI y XVII, ver Otero Lalana, especialmente pp. 255-260 y ss. 15. Ver Murrin, 1994, p. 154.

16. Ver el estudio de Enrique Otero Lana. Las relaciones entre corso, política y negocios podían Ilegar a ser muy sutiles: por ejemplo, entre ciertos marinos vascos del siglo XVI, quienes abordaban buques franceses tras haber pactado con la corona un reparto de beneficios. En ocasiones, estos corsarios se excedían en sus prerrogativas y actuaban con demasiada violencia en busca de mejores ganancias lo que obligaba a nuevas negociaciones con las mismas autoridades españolas (ver Azpiazu, 2004, 69-

77). Pero estas mismas negociaciones revelan la sujeción a la legalidad que requería el corso frente a la piratería.

17. Ver Nakashima, 2014, p. 309

18. Ver Castellanos, 1921, pp. 366-376.
} 
combinaba con la defensa militar de su nación, según las circunstancias. Richard Hawkins, quien intentó sin éxito emular las hazañas circunnavegadoras de Drake y Cavendish, aparte de asolar las costas españolas del Pacífico, escribió lo siguiente acerca de sus propósitos de viaje:

The principal end of our designements was to make a perfect discovery of all those parts where I should arrive, as well known and unknowne, with their longitudes and latitudes; the lying of their coasts; their head-lands; their ports, and bayes; their cities, townes and peoplings; their manner of governement; with the commodities with the countries yeelded, and of which they want, and are in necessitie ${ }^{19}$.

En caso de guerra declarada los ataques a costas enemigas y objetivos civiles se concebían como medios naturales de conducirse entre militares. La profesión de corsario no era considerada innoble. Richard Hawkins se quejaba en sus memorias de que, al ser capturado por los españoles, fuese considerado por algunos de ellos como pirata, aunque estuvieran en tiempos de conflicto. El corsario inglés u holandés de fines del XVI y comienzos del XVII no se representaba a sí mismo como un delincuente. Como ha mostrado Fuchs, dos piezas dramáticas inglesas de comienzos del siglo XVII, Fortune by Land and Sea de Rowley y The Fair Maid of the West de Heywood, mostraban la actividad corsaria como propia de una nación que se imaginaba valerosa, gallarda y, lo que es más importante, afortunada ${ }^{20}$. Según se desprende de estas obras, emprender ataques de rapiña contra buques mercantes españoles se revestía de honorabilidad, ya que vendría a vengar agravios previos procedentes de la misma España. De hecho, esto era visto como una forma de restaurar el honor nacional y sellar la distinción entre españoles e ingleses. The Fair Maid of the West se abre, por ejemplo, con un elogio del saqueo de Cádiz, así como una exaltada y algo prematura alabanza de la expedición británica que iba a combatir en las Azores ${ }^{21}$.

Por supuesto los españoles podrían extrañarse de la autorrepresentación de su enemigo, a quien consideraban un simple pirata, con independencia de sus circunstancias. Pero no tenía nada de extraño que a los ingleses les repugnase esta imagen. Por lo que se deduce de cierto pasaje de las Elegías de varones ilustres de Indias, Francis Drake tampoco admitía un trato semejante, ya que sus empresas pasaban por ser de entrada comerciales desde su punto de vista. Según el poema de Castellanos, tras la toma de Cartagena, Draque se reúne con las autoridades coloniales y se queja públicamente de que rey de España lo considerase como un pirata en una cédula firmada por aquel. Juan de Castellanos lo refiere en unas octavas bien interesantes, ya que allí se atreve a poner las razones del antagonista en su propia boca:

Prosiguiéronse las conversaciones

ajenas de católico provecho

y el inglés, de razones en razones,

19. Hawkins, Observations of Sir Richard Hawkins in his voyage into the Sutth Sea, p. 7

20. Ver Fuchs, 2001, pp. 125-132.

21. Ver Fuchs, 2001, p. 130 
favoreciendo siempre su derecho,

disimular no pudo las pasiones represadas en el soberbio pecho: porque su Majestad tan mal lo trata en ponelle renombre de pirata.

Y dijo: «Bien sé yo que grandiosa potencia de monarca soberano no siempre puede bien leer la cosa que le dan a que firme de su mano; fiasse de la gente generosa, del leal y probado cortesano y esta cédula fue por esta vía firmada, sin leer lo que decía. Mas a cualquier señor inventor de esta palabra baja, si me la escribiera, no se tardara mucho la respuesta, porque sin duda yo le desmintiera....»22

El efecto es notoriamente dialógico, ya que las palabras de Draque, aunque motejadas de locas y soberbias, pueden leerse hoy como un reflejo abierto de la mirada del otro. Para comprender la representación que de sí mismo hace el corsario inglés que se niega a ser considerado un vulgar pirata, esa palabra baja (palabra que podría igualarlo, por ejemplo, a los berberiscos), hay que recurrir a la actuación de este colectivo en los mares recién descubiertos. Castellanos, de un modo intencionadamente dialógico, precisa el término «pirata» y no recurre a «corsario». La elección del vocablo más aceptable como denigrante apela al consenso peyorativo tanto entre españoles como ingleses. De esta forma se traslada el discurso del enemigo con una fidelidad léxica y semántica notables. Todo ello indica, a mi modo de ver, una momentánea empatía con el otro, por más que las palabras de Draque hayan brotado de «soberbio pecho».

\section{EL LUTERANO}

Junto a la admonición del pirata, en los discursos épicos se acumula otra referencia que carga aún más las señas negativas del corsario inglés: el hecho de ser «luterano». El tempestuoso escenario político religioso que se vive en Europa se traslada a América, con toda su batería de prejuicios contra aquellos que se declaren enemigos de la Iglesia de Roma. La adhesión al anglicanismo o a cualquier rama del protestantismo implica un alejamiento que va más allá de las fronteras nacionales. Los enemigos protestantes de España no son auténticos cristianos, aunque se les reconozcan otras virtudes. Barco Centenera, después de realizar un elogio de las cualidades humanas y militares de Draque, declara:

Mas como lo mejor y más necesario

le falta, que es amor de Jesu Cristo,

22. Castellanos, 1921, p. 208

HIPOGRIFO, 4.1, 2016 (pp. 43-63) 
emprendió de hacerse gran cosario

y fuelo tal cual nunca se había visto ${ }^{23}$.

Desde este punto de vista, una separación de la fe católica, incluso, puede apartar al individuo de forma absoluta del mismo Jesucristo, del mismo amor que representa. como es el caso de Drake. La figura del pirata o corsario se dibuja con un perfil singular que depende del contexto político europeo, tan marcado entonces por las guerras de religión. Por eso el inglés, francés u holandés no sólo es visto como un enemigo no comercial, sino principalmente religioso. Tanta es la fuerza sugestiva en el imaginario católico español de la época, que el mismo nombre de «luterano» pasa a ser un estigma de todo enemigo del imperio que se aventure a saquear presas en el Caribe o en el Mar del Sur ${ }^{24}$. La palabra «luterano» aparece repetidas veces en las informaciones de méritos y servicios de vasallos del rey español que aseguran haber empeñado riquezas y esfuerzos en la defensa de los territorios americanos contra los acosos de piratas. No importa si Draque, Hawkins o Cavendish fueron propiamente anglicanos y no seguidores de Lutero ${ }^{25}$. La distinción teológica no entra generalmente en muchas sutilezas. En realidad, cualquier herejía es indiscernible de otra en la medida en que supone una amenaza a la interpretación oficial de la colonización. Bartolomé Leonardo de Argensola en La conquista de las Molucas, escribe de Drake lo siguiente: «Este fue el primero que abrió el paso a los sectarios hugonotes, luteranos y calvinistas que después pasaron a aquellos mares, con navíos cargados de textos pervertidos, Biblias heréticas y otros libros de inficionada doctrina ${ }^{26}$.

La noticia de que los corsarios ingleses pudieran traer libros heréticos destapa el miedo a una posible conquista espiritual protestante para el imperio católico recién formado en América ${ }^{27}$. Recordemos la interpretación providencialista con que los españoles interpretan su propio proceso colonizador: América se habría convertido en el continente otorgado por la Divinidad a España para compensar la pérdida de almas para la Iglesia tras la Reforma protestante en Europa. En 1596 el religioso franciscano Jerónimo de Mendieta contaba la historia de la reciente conquista de México a partir de esta explicación tan extendida. Hernán Cortés había sido elegido por la Providencia:

para por medio suyo abrir la puerta y hacer camino a los predicadores de su Evangelio en este nuevo mundo donde se restaurase y se recompensase la Iglesia católica con conversión de muchas ánimas, la pérdida y daño grande que el maldito Lutero había de causar en la misma sazón y tiempo en la antigua cristiandad²8.

23. Barco Centenera, Argentina y conquista del Río de la Plata, p. 323.

24. La admonición antiluterana en América persiste primero contra Inglaterra y después contra Holanda en relaciones, representaciones teatrales, pinturas, etc. por lo menos hasta 1648, fecha en la que España firma la paz de Münster (ver Usunáriz, 2011, pp. 168-172).

25. Nakashima, 2014, p. 311

26. Argensola, La conquista de las Molucas, p. 108

27. Ver Nakashima, 2013, pp. 9-10.

28. Mendieta, 1945, p. 12. El providencialismo hispano con respecto a América se inaugura con el Libro de las profecías preparado por Colón en donde se asegura que los Reyes católicos habrían de recons- 
Miramontes se hace eco desde la voz épica de la misma idea: «Viendo que en Francia, Flandes, Alemaña, / Ingalaterra, Escocia, Albania, Hungría, / la integridad catholica se daña / por la prevaricante apostasía [...] quiso [Dios] que si Calvino y Luthero, / [...] apartan por herético sendero, / de la romana Iglesia un largo estadio / gente infinita, que infinita gente / el español la agregue ya paciente» (Miramontes, Armas antárticas, pp. 168-169). Desde la propaganda oficial, la misión histórica de España era la difusión de la fe católica en el Nuevo Mundo cuando se habían perdido millones de almas en Europa por la Reforma protestante. La presencia de corsarios ingleses y holandeses sólo podía explicarse como una contraofensiva satánica que hacía peligrar el orden católico recién impuesto en América. La muerte del «Draque», acaecida en 1596 durante su última expedición a América, era una señal de que Dios actuaba del lado español. En la Dragontea (1598), poema escrito para la ocasión, Lope de Vega imagina al corsario como un individuo maléfıco que ha hecho un pacto con el diablo ${ }^{29}$. Al reunir dentro de sí las características doblemente negativas de saqueador y hereje, el pirata se convertía en el perfecto aliado del diablo para una sociedad colonial que había atribuido al poder de Satanás la existencia de los rituales indígenas y que había luchado contra ellos con el mismo denuedo que contra los ejércitos nativos ${ }^{30}$.

El saqueo de lugares e imágenes católicos forma parte del discurso recurrente antipirático, más que el de, por ejemplo, los atropellos a la población civil. Juan de Castellanos rememora el saqueo de Cartagena por parte de las huestes de Drake:

Corrió la furia por los monasterios,
do Dios se sirve con divinos cantos,
hicieron nunca vistos vituperios
en imágenes santas de los santos
y en el Señor de todos los imperios
y de su Virgen Madre, tantos cuantos
pudiera hacer ánima perdida
de todos los demonios revestida

Parecidas denuncias señalan Lope de Vega en su Dragontea o Barco Centenera de las rapiñas de Cavendish ${ }^{32}$. Ahora bien, este tipo de sacrilegios formaban parte de las acciones comunes en las guerras de religión en territorio europeo, ya fuera cometido por uno u otro bando. De ahí que el corsario inglés lo que haría es prolongar un modo de combate en el Viejo mundo, con lo que así legitimaba desde su perspectiva su empresa militar. Sabemos también que Drake llevaba Biblias protestantes y curas anglicanos en sus navíos, un pertrecho más inverosímil, por cierto, en los bucaneros del siglo XVII. Naturalmente para los españoles este tipo

truir la ciudad de Sión en las nuevas tierras conquistadas (ver Saranyana y Zaballa, especialmente pp. 167-169). A lo largo del siglo XVI estas ideas van circulando desde la predicación a los textos profanos con clara intención político religiosa.

29. Ver Segas, 2015.

30. Ver, por ejemplo, López Meraz, 2008, pp. 121-155

31. Castellanos, 1921, p. 211

32. Ver también Segas, 2015, p. 25. 
de aditamentos no atenuaban la maldad de sus acciones, sino que más bien la confirmaban.

\section{EL ELOGIO DEL ADVERSARIO}

El pirata es el enemigo exterior por excelencia, frente al indio o el cimarrón, quienes se oponen desde dentro al dominio colonial. Pero, para alcanzar un estatus de tal magnitud, este personaje tiene que atesorar virtudes que lo hagan digno del enfrentamiento con el héroe español. En los diversos poemas dedicados a las hazañas de Francis Drake, también conocido como el ciclo de Drake (1586-1610), no sólo se comprueba el peligro real que representaba el gran navegante inglés para los intereses españoles sino también una cierta admiración por él33. Esta ambivalencia, por cierto, no se aplica al personaje histórico de Drake, sino que se puede encontrar en los retratos de Oxenham, Richard Hawkins o Cavendish escritos por Miramontes, Oña o Barco Centenera. El discurso épico modela un arquetipo de corsario que se adorna con virtudes intelectuales (sagacidad, prudencia, astucia), morales (reciedumbre, valentía), físicas (fortaleza, aptitud para la navegación) e incluso sociales (liderazgo, cortesanía). Frente a las cualidades humanas del archienemigo, los españoles no siempre salen bien tratados. Barco Centenera dedicó parte del canto XXII de su poema al raid de Draque por el virreinato del Perú y lo filtró desde una perspectiva muy crítica. Según él, las reacciones de los sorprendidos españoles tendrían muy poco de heroicas: «La turbación y prisa yo decilla, / aunque quiera hacer un largo canto, / no podré: cabalgaba uno sin silla, / el otro con silla aunque con espanto, / el otro iba sin freno en su haquilla; el pecador temía y el más sancto» ${ }^{34}$. Tanta cobardía colectiva no es en absoluto la perspectiva de Miramontes, quien reconoce, sin embargo, que las armas estaban echadas en el olvido cuando se presentan los luteranos. En todo caso, la alabanza del pirata reproduce distintas respuestas en el poema épico, representativas de una comunidad en crisis, convulsionada ante una amenaza exterior imprevista. El miedo, la codicia o la traición de los intereses comunes salen a la luz en Barco Centenera o en Castellanos; en Miramontes las referencias son menos críticas, pero dejan entrever un peligro que no se despeja de forma definitiva.

En apariencia, si la épica colonial estuviera al servicio directo del discurso oficial, poco ganaba con proponer una imagen positiva y heroica del enemigo. A esta objeción se podría aducir que históricamente la épica siempre ha enaltecido las armas del antagonista como un procedimiento de favorecer las del propio ejército. Héctor y Turno, en la llíada y la Eneida, configuran el modelo del perfecto enemigo, valeroso y noble. Ciertas lecturas de La Araucana han juzgado la valoración positiva de los indígenas desde estos parámetros. La gloria de los españoles, al vencer, es mayor si se considera la categoría moral y militar de sus enemigos.

33. Para Lise Segas, Drake se convierte en «el perfecto héroe épico» en la épica culta española (2015, p. 20)

34. Barco Centenera, Argentina y conquista del Río de la Plata, p. 326. 
Sin embargo, esta explicación, pese a su fuerza persuasiva, puede valer en algunos casos (Armas antárticas), pero requiere de matices y no es del todo operativa en algunos de los poemas que comentamos. En Barco Centenera, siempre poco complaciente, es posible ver un cierto derrotismo en la presentación de las batallas. La denuncia de la pereza o la indolencia de las autoridades de Cartagena ante la cercanía de los ingleses mueve a Castellanos en su Discurso del capitán Draque ${ }^{35}$. Por eso, al margen de una plausible, pero incompleta, explicación sobre la vía de la tradición, quizá se pueda atender a otras razones de orden político que trascienden la doctrina de la imitatio. Es verdad que en Miramontes la alabanza del enemigo enaltece a las armas españolas, quienes al final acaban venciendo... en su relato. Su elogio no es, por tanto, una simple muestra de caballerosidad, sino que responde a una voluntad más amplia de apoyar las medidas defensivas tomadas por las autoridades. Estas sentían el peligro que significaba la entrada de enemigos luteranos en todos los rincones del Imperio. Cristóbal Suárez de Figueroa, autor de Hechos de don García Hurtado de Mendoza (1613), panegírico patrocinado por el mismísimo interesado y antiguo virrey del Perú no duda en situar las hazañas marineras de los corsarios junto a las de Vasco de Gama, Magallanes, Cortés y Pizarro:

Valientes fueron (no se niegue) los atrevimientos de Draque, Candi y Aquines, émulos de Magallanes, pues atravesando de Norte a Sur el estrecho de su nombre vinieron a turbar los mares que tuvieron por máxima, desde infinitos años atrás, el ser seguros y pacíficos ${ }^{36}$.

Al cruzar el Estrecho de Magallanes y saquear las costas del virreinato del Perú en 1579, Drake abrió un portón hasta entonces inexpugnable y alertó a los virreyes españoles sobre la necesidad de reforzar las medidas de defensa. En este sentido, las versiones que se dieron de los siguientes ataques se ven en la necesidad de exaltar o criticar la capacidad de reacción de las autoridades ante amenazas imprevistas. Es una épica defensiva la que se consagra a partir del ataque de Drake a la costa del Pacífico, porque desde entonces todos los dominios españoles se sienten vulnerables. La Argentina y conquista del Río de la Plata se cierra con la derrota in extremis de Cavendish en su segunda expedición, lo cual no impide que se denuncien las limitaciones políticas y militares en el flanco sur del imperio ${ }^{37}$. El ensalzamiento del corsario implica también el reclamo de medidas contra él La épica no duda en mostrar la categoría del enemigo y sus hipotéticos planes de conquista. En este sentido, no hace sino reflejar los miedos y preocupaciones de la clase letrada colonial ${ }^{38}$.

35. De todos modos, no disponemos hoy de todo lo que escribió Castellanos sobre Draque, ya que, al parecer, su relato concluiría con la derrota y muerte de Drake en Portobelo. El manuscrito donde se refiere el final se encuentra perdido (Segas, 2012, p. 29).

36. Suárez de Figueroa, Hechos de don García Hurtado de Mendoza, p. 277.

37. Ver Navascués, 2013, pp. 189-190.

38. Una interesante excepción podría constituirla el poema épico burlesco «La victoria naval peruntina», que parodia el final del Arauco domado de Pedro de Oña. En el texto, basado en la batalla de Beltrán de Castro frente a Richard Hawkins, se disminuye la seriedad de la amenaza corsaria a partir de la 


\section{LA MÍMESIS DEL PIRATA}

Entre los atributos del «perfecto héroe épico» pueden encontrarse tanto ciertas virtudes como aquellas otras conductas que nacen de la hybris, el furor o la codicia. La extremosidad en las cualidades positivas puede conducir a un apetito exagerado por el provecho material, un deseo inmoderado de placer, fama o riquezas del que no están exentos los héroes clásicos ni los grandes guerreros de la épica tradicional. En el ámbito americano los piratas Drake o Cavendish imitan, en su exceso de fortuna y en su temeridad, a los conquistadores españoles representados en crónicas y poemas épicos. La codicia, motor de las acciones del corsario, y la falta de respeto por la ley también afectan antes a Valdivia y a sus españoles desde los primeros cantos de La Araucana ${ }^{39}$. La soberbia pierde a Juan de Garay, quien según Barco Centenera, «de prudencia fue siempre falto» ${ }^{40}$. Y es la demasiada confianza en sí mismo ("su vana fantasía» ${ }^{47}$ ) la que lleva a la desgracia a Cavendish en su segunda y trágica expedición a América. Los piratas emulan a los conquistadores, con quienes tienen puntos de contacto... En el modelado de la alteridad pirática no sólo se establecen diferencias, sino también relaciones de equiparación. Estas analogías, por supuesto, no implican una exacta identificación, pero, como veremos a continuación con un ejemplo más detallado, puede derivar en inquietantes conclusiones para el lector contemporáneo. Si los piratas imitan en sus prácticas a los conquistadores, su potencial agresividad aumenta.

Para establecer mejor esta relación de imitación, que concluye en emulación alarmante, me centraré en el Canto III de Armas antárticas, en el cual el pirata Draque expone ante la reina Isabel I sus planes de conquista de América. Se trata de un texto que seguramente debería leerse encajado en una tradición imitativa que tiene a Juan de Mena, Camoens y Ercilla como eslabones anteriores a Miramontes ${ }^{42}$. Los poemas fundamentales de estos tres autores tienen un episodio en el que se muestra por arte sobrenatural un panorama del globo terrestre, con profusión de lejanos lugares geográficos conocidos en la época de su escritura. Los tres imaginan un personaje que presenta lugares distantes con verbos de visu que introducen la descripción. Juan de Mena en su Laberinto de Fortuna escribe: «Vi de Eufrates al Mediterráneo, / a Palestina e Fenicia la bella, / dicha del fénix que se cría en ella, / [...] e vi Comagena con toda Siria, / e los nabateos que agora splano» ${ }^{43}$. De forma aná-

ridiculización de las autoridades y los héroes españoles. Tal vez sea significativo que el corsario no sea denominado «luterano», sino «anglicano», variación excepcional en los textos sobre el tema.

39. «Crecían los intereses y malicia / a costa del sudor ajeno, y la hambrienta y mísera codicia, / con libertad paciendo iba sin freno. / La ley, derecho, el fuero y la justicia / era lo que Valdivia había por bueno: remiso en graves culpas y piadoso, y en los casos livianos riguroso» (Ercilla, La Araucana, p. 104).

40. Barco Centenera, Argentina y conquista del Río de la Plata, p. 352.

41. Barco Centenera, Argentina y conquista del Río de la Plata, p. 387.

42. Como estudió con detalle Nicolopulos, se puede trazar una secuencia a partir de las escenas mencionadas aquí de Mena, Camoens y Ercilla. Cada uno de los tres autores plantea una visión imperialista del mundo y es posible leer la rivalidad entre las dos potencias ibéricas en Camoens y Ercilla (Nicolopulos, 2000, pp. 236-264). Asimismo, para una interpretación complementaria de la mía en las páginas siguientes, puede verse el artículo de Mc Closkey, 2013, pp. 393-415.

43. Mena, 1982, p. 95. 
loga, Camoens sitúa a la diosa Tetis enseñando a vasco de Gama lejanos países desde Asia a Europa con especial énfasis en aquellas tierras que se someterán al designio portugués. A su vez, Ercilla, incluido como personaje en su poema es conducido por el mago araucano Fitón hasta una cueva en donde recibe la experiencia de una esfera mágica en la que se ve todo el mundo desde Asia a América. Como estudió Nicolopulos, detrás de estos tres episodios maravillosos, el poeta épico sostiene una visión imperial del mundo desde su propia perspectiva nacional. Mena esboza desde una óptica cortesana un proyecto de conquista del mundo para Juan II de Castilla. Camoens traza un mapa del mundo en el que España y Portugal surgen como la cabeza de la civilización europea, pero en donde el reino lusitano tiene la primacía ibérica. Por último, Ercilla rivaliza con el gran poeta portugués al incluir el Nuevo Mundo, ausente en Los Lusíadas. La emulación entre españoles y portugueses por el dominio de los mares queda de manifiesto en el modo de presentar la geografía en La Araucana y Los Lusíadas respectivamente.

Miramontes sin duda conocía de cerca los tres poemas mencionados. En las Armas antárticas Draque muestra un mapa del mundo a la reina Isabel de Inglaterra. Desde un punto de vista formal, hay elementos comunes como el empleo del verbo de percepción «Ver» con una función introductoria de los espacios geográficos mencionados en las octavas dedicadas al mapamundi. Lo interesante es establecer cómo se produce el diálogo con la tradición al suplantar el discurso de un sabio enemigo (Fitón) o una diosa pagana (Tetis) por un pirata (Draque), al mismo tiempo que este último expone sus planes de dominación del mundo hispano ${ }^{44}$. La idea de rivalidad, entonces, que podía percibirse en la reescritura del tema en Ercilla respecto de Camoens, se intensifica al ser un luterano inglés quien protagoniza el saber discursivo. El corsario no sólo sobresale por su audacia, sino por su saber discursivo: es el enemigo por excelencia.

Para favorecer sus argumentos, el marino inglés acude al recurso del exemplum, en este caso, un vasto discurso sobre la navegación de Magallanes. De esta manera se señala la oportunidad de realizar un viaje semejante. Puede suponerse

44. Lope de Vega, en su Dragontea, tiene una escena similar. Drake irrumpe en los dos poemas con una exposición ante la reina Isabel I de sus proyectos de ataque y saqueo de las posesiones españolas en América. Ahora bien, en Lope el discurso del corsario viene precedido de un sueño en el que una figura alegórica de la Codicia recién llegada de los infiernos se le aparece a Drake. Miramontes, más realista y menos alegórico, introduce a su personaje directamente en la corte inglesa, donde persuadirá a la reina del interés de su empresa. El Draque de Miramontes no se adorna con los improperios que Lope de Vega le dedica en su Dragontea desde España. En Armas antárticas no se le asocia recurrentemente con el simbolismo satánico del dragón, ni se le adjudica un pacto con el diablo. Tampoco se cuentan sus fracasos en la Coruña y Lisboa (1589), su etapa de caída en desgracia, ni la expedición colmada de derrotas que le llevó a la muerte en Portobelo (1596). Todo esto podría haberse destacado, pero, muy al contrario, la actuación del corsario inglés se enmarca en su apoteosis histórica en América, cuando franquea el Estrecho, toma algunos mercantes, saquea el galeón Nuestra Señora de la Concepción y escapa de los españoles rumbo a Inglaterra con la perspectiva de convertirse en el segundo navegante en circunnavegar el globo terrestre. Es cierto que, al hacer hincapié en su audacia de marino, Miramontes establece un diálogo con toda una tradición retórica de denuncia de la codicia, pero lo hace sin la ferocidad de la Dragontea. 
un cierto desafío a la hora de introducir argumentos contrarios a la ideología auctorial cuando el personaje-enemigo se expresa en un estilo elevado. Miramontes esquiva el riesgo al basar las razones de su Draque en la emulación del héroe portugués. De nuevo se advierte la relación de rivalidad e inspiración de uno sobre otro. Aquí se estaría estableciendo de forma implícita la superioridad de Magallanes, portugués al servicio de España, ya que él llegó primero que el inglés a superar el Estrecho. Pero la intención quizá vaya más allá, porque el relato del Draque se deleita en recorrer los lugares de la geografía americana que Magallanes podría haber surcado si su derrotero hubiera sido otro distinto del que fue. Como se sabe, después de atravesar el Estrecho, Magallanes puso rumbo al Pacífico y no tocó las costas del Perú. Ahora Draque pone delante de la imaginación de su reina y mecenas ese viaje que él sí va a realizar. El mago Fitón de La Araucana, en su exposición planetaria, había recordado el itinerario de Magallanes («y el estrecho / por donde Magallanes con su gente / al Mar del Sur salió desembocando... $\rangle^{45}$ ) y acompañaba la descripción de unos apelativos «vee» o «mira» dirigidos a su interlocutor, Ercilla. Ahora bien, su recorrido se detenía en ciudades, ríos, lagos e islas de Arauco.

$$
\begin{aligned}
& \text { Vees la ciudad de Penco y el pujante } \\
& \text { Arauco, estado libre y poderoso; } \\
& \text { Cañete, la Imperial y hacia el levante } \\
& \text { La Villa Rica y el volcán fogoso... }{ }^{46}
\end{aligned}
$$

Penco, Chiloé, Bío Bío, la Imperial, Cañete, Valdivia, etc. A continuación su mirada se movía hasta el sudeste asiático, donde murió Magallanes peleando. A diferencia de Fitón, el Draque de Miramontes se detiene en nombrar con sumo detalle una serie de puertos del Pacífico a los que no llegó el marino portugués al servicio de España. Todos estos espacios nunca habrían sido hollados por la expedición de 1520, pero al pirata sí le interesan. Como agudamente observa Firbas, el verbo que acompaña al sujeto «Magallanes» no es «vio», sino «viera» ${ }^{47}$. Todo un mundo de deseos se le abre al corsario:

$$
\begin{aligned}
& \text { Viera al principio de la costa rica } \\
& \text { los pelados desiertos de Atacama, } \\
& \text { Tarapacá, Marormoreno y Arica, } \\
& \text { Isla de Guano, a Tacana y a Sama. } \\
& \text { Viera a Chule, la Nasca, y fértil Ica, } \\
& \text { Pisco, Chincha, Cañete, Pachacama, } \\
& \text { Callao, Guaura, Guarmey, Barranca Santa, } \\
& \text { Trujillo, Payta, Guayaquil y Manta }{ }^{48} \text {. }
\end{aligned}
$$

La expresión de subjuntivo remite a un anhelo que se atribuye no a Magallanes, sino al propio Drake y la reina Isabel, codiciosos de las riquezas ajenas. Puestos estos nombres de lugares americanos en boca del corsario, el enunciado cobraría

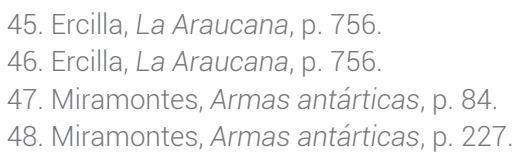


para el lector implícito un sentido muy preocupante. Conviene recordar que el mayor conocimiento de la geografía mundial, así como los continuos progresos en la cartografía, estuvieron al servicio de las empresas imperiales de la época. Según Pedro Sarmiento de Gamboa, Drake se jactó ante los prisioneros del galeón apresado de San Juan de Antón de tener una espléndida carta náutica de los mares del Sur, adquirida en Lisboa ${ }^{49}$. La posesión de un mapa de estas características podía ser vista con enorme alarma por las autoridades españolas, quienes se habían mostrado extremadamente sigilosas en la transmisión de los nuevos conocimientos geográficos. Recordemos que la Casa de la Contratación de Sevilla, primera institución oficial creada para el conocimiento de los saberes náuticos, puso gran interés en la confección de mapas de los territorios recién descubiertos. Entre sus funciones estaba la de trazar los mapas o cartas de navegación y el conocido como «padrón real», mapa modelo del Nuevo Mundo donde se iban registrado todos los descubrimientos. La Casa custodiaba la información náutica y la cartografía de manera secreta para evitar que la información cayera en manos de potencias extranjeras. En el siglo XVI, como se ha señalado alguna vez, la elaboración de los mapas era una operación que iba acompañada de un ideario imperial ${ }^{50}$. Manejar una ajustada información cartográfica era un comienzo de apropiación del espacio. La poesía hispana ya disponía de ejemplos en los que un personaje dibujaba con la imaginación una suerte de mapa con lugares de inmediato asociados al proyecto imperial sobre América ${ }^{51}$. La cartografía en la épica, pues, no era un recurso inocente. El hecho de que un «luterano» inglés nombrase ordenadamente una serie de lugares prohibidos para él, podía ser leído como una prueba evidente de futura agresión. De ahí que la sucesión de topónimos desde el sur de Chile hasta Acapulco, pronunciada por el corsario, tenga un carácter subversivo en el contexto en que se inscribe. El enemigo, vendría a decirse, conoce las cartas náuticas que le permitirán llegar hasta el último rincón del imperio. Y apoderarse de él.

\section{CONCLUSIONES}

La alteridad en el discurso colonial ha acostumbrado a postularse «en términos de género y de etnia» ${ }^{52}$. Cabe preguntarse si las representaciones de los piratas luteranos en la épica puede introducir otros factores de alteridad como el religioso. El argumento de la lucha contra el protestante en Europa, elevado a criterio supremo de la política exterior española, por lo menos hasta el final de la Guerra de los Trein-

49. Ver García Redondo y Varela, 2013, pp. 441-478.

50. Para la relación entre el ideario imperial y la cartografía, ver Ricardo Padrón. Respecto del primer mapa sobre la circunnavegación de Magallanes, afirma este autor que «it is the power and not just the daring of early modern Iberians that make the surface of this map. Gilt lines across the Atlantic, tracing the routes of Spanish treasure fleets, attesting to Spain's conquest of the sea in the creation of a transAtlantic empire. Their presence reminds us of the imperialistic motives behind Magellan's expedition» (Padrón, 2004, p. 3)

51. Ver Blanco, 2102, pp. 392-394, con textos de Bernardo de Balbuena y algunos épicos menores.

52. Adorno, 1988, p. 66 
ta años (1648), reforzaría el proyecto de identidad católica de la naciente sociedad colonial americana.

Por otra parte, ya hemos visto que la conformación de la alteridad implica un juego de distanciamientos y similitudes. La oposición con respecto a los conquistadores españoles se funda en una oposición basada en dos principios. En primer lugar, el inglés es un pirata fuera de la ley. Los textos épicos menosprecian las diferencias legales que en la época se admitían entre la piratería y la guerra de corso, a pesar de que la misma España incurrió en ella y favoreció a corsarios propios. En segundo lugar, el pirata es motejado de luterano. Por este doble motivo, el hecho de ser un sujeto fuera de la ley humana y divina, se enfrenta a la visión a partir de la cual se construye el sujeto colonial americano de los siglos XVI a XVIII, una visión sostenida en un discurso que privilegia una percepción masculina, caballeresca y cristiana del mundo ${ }^{53}$. El retrato del pirata-corsario es el del de un sujeto perturbador del orden legal, pero también político religioso querido por la Providencia ${ }^{54}$. No extraña que Drake y sus seguidores se alíen con los enemigos internos del sistema: esclavos fugitivos o indios alzados. El pirata no es un simple delincuente; su peligrosidad va más allá al representarse como agente de una subversión cósmica.

Ahora bien, junto al antagonismo se detecta también una percepción admirativa del enemigo audaz, valeroso y hábil navegante. Respecto a la configuración de la imagen del pirata puede hablarse no sólo de una alteridad excluyente, sino también de la expresión de actitudes valoradas por el sujeto colonial respecto de sí mismo. Al igual que famosamente sucede en La Araucana con el indígena, el otro se ensalza a partir de cualidades que el discurso épico asume como propias. La celebración del valor del enemigo, rasgo épico notable ya en la tradición clásica, se establece en razón del carácter civilizado del corsario inglés ${ }^{55}$. La relación entre el héroe español y el corsario se manifiesta entonces no en un sentido vertical, como podría suceder entre el conquistador y el indígena o el esclavo, sino en un plano de rivalidad. Se disuelve la dialéctica entre sujeto colonizador y colonizado que se encuentra en el centro de la vida colonial; más bien al contrario, esta se reemplaza por la rivalidad entre un sujeto colonizador en acto y otro en potencia. De nuevo el discurso religioso expresa aquí su fecundidad para entender la configuración de la alteridad. La posibilidad imaginaria de que los corsarios ingleses importen el protestantismo a América, con la posible colaboración de esclavos, cimarrones e indígenas, se inscribe en los poemas épicos para señalar un peligro cierto de una nueva colonización europea que arruine el proyecto de la nueva Cristiandad que habría emprendido España. El pirata, entonces, no es otro al que se aspire a dominar mediante las armas o la palabra, sino alguien que amenaza el orden colonial establecido. Su antagonismo debe entenderse dentro de una estrategia global de

53. Ver Adorno, 1988, pp. 55-57.

54. Frente a las amenazas de turcos, berberiscos en el Mediterráneo, y protestantes en el Atlántico y el Pacífico, España se ve a sí misma como campeona de la fe católica. Su épica es defensiva. La Dragontea sería un buen ejemplo (Fuchs, 2001, pp. 141-150), pero también los textos que aquí hemos analizado. 55. Mazzocchi (2016, p. 141), al respecto, destaca el carácter caballeresco de los corsarios en Armas antárticas. 
conflicto que abarca a Europa y América. Por eso su derrota pasa no tanto por ser aniquilado, sino al menos expulsado del territorio americano. Así sucede en todos los casos, desde los fracasos de Oxenham, Hawkins y Cavendish ${ }^{56}$, hasta la huida, por muy victoriosa para los ingleses que fuera desde el punto de vista militar, de Drake en Armas antárticas y Discurso del capitán Draque.

Muchas veces el pirata no es derrotado de forma absoluta. Esto trae consigo que su retrato se presente con alguna ambigüedad, sobre todo en aquellos textos épicos gestados en la Colonia. Frente al diabolismo de Draque en la Dragontea de Lope, texto escrito en la Península e imbuido del discurso oficial que destaca el final del enemigo, los poemas de Barco Centenera, Miramontes y Castellanos no siempre narran una derrota total (a veces, incluso, señalan la victoria del inglés) y aceptan valores positivos de éste, aunque por supuesto no nieguen su maldad intrínseca. El pirata, al establecer una relación de rivalidad, copia a los españoles, tanto en sus virtudes como en sus defectos. En las Armas antárticas Draque y Candís son nobles caballeros que terminan alejándose oportunamente de América; en la Argentina y conquista del Río de la Plata, este último acaba pereciendo víctima de su soberbia, igual que les ocurre a otros héroes españoles en el desengañado poema de Barco Centenera. Especial interés adquiere el Canto III de Armas antárticas. Allí la pericia navegante del corsario y su conocimiento cartográfico del mundo emulan tanto las hazañas históricas de Magallanes como ciertos pasajes de La Araucana y, más lejanamente del Laberinto de Fortuna. Esa copia se vuelve inquietante para esa épica que representa, no siempre de forma deliberada, las tensiones de un mundo colonial que se ve enfrentado a crisis inesperadas ${ }^{57}$.

\section{BIBLIOGRAFÍA}

Adorno, Rolena, «El sujeto colonial y la construcción cultural de la alteridad», Revista de crítica de la literatura latinoamericana, 14, 28, 1988, pp. 55-68.

Anónimo, La guerra de Chile, ed. Mario Ferreccio y Raïssa Kordic, Santiago de Chile, Universidad de Chile, 1996.

56. Todos ellos referidos respectivamente en Armas antárticas, Arauco domado y La Argentina y conquista del Río de la Plata.

57. Las expediciones corsarias nunca fueron en términos militares una amenaza objetiva a la subsistencia global del Imperio español en América. Otra cosa es que su presencia revelara tensiones en el consolidado sistema colonial. Un punto importante que no puedo desarrollar aquí por falta de espacio es la utilización del poema épico como medio para recibir favores reales a sujetos que no se sentirían suficientemente satisfechos de recompensas. Como señala Segas, los poemas épicos «ofrecen diferentes modalidades narrativas pero todos desarrollan la misma estrategia al valerse del corsario inglés luterano como del perfecto enemigo herético épico para hacer resaltar las hazañas de sus héroes históricos, verdaderos milites dei al servicio del rey, para quienes pedían reconocimiento y gratitud» (Segas, 2015, p. 20). Oña o Miramontes, por ejemplo, se valen del recurso épico de la revista de tropas antes de la batalla para hacer desfilar a los héroes, encomenderos o caballeros españoles y criollos con nombre y apellidos que se distinguirían en la lucha contra el adversario. Se trataría de una estrategia retórica distinta, pero con una finalidad semejante a la de las Relaciones de méritos. 
Anónimo, La victoria naval Peruntina, Ms. 3912, Biblioteca Nacional de Madrid, s/f.

Argensola, Bartolomé Leonardo, La conquista de las Molucas, Madrid, 1609

Balbuena, Bernardo de, El Bernardo, o Victoria de Roncesvalles, Madrid, Flamenco, $1624<$ http://digital.onb.ac.at/OnbViewer/viewer. faces?doc=ABO_\%2BZ182770001> [14/03/2016].

Azpiazu, José Antonio, Historias de corsarios vascos. Entre el comercio y la piratería, San Sebastián, Ttarttalo, 2004.

Barco Centenera, Martín del, Argentina y conquista del Río de la Plata, ed. Silvia Tieffemberg, Buenos Aires, UBA, 1998.

Blanco, Mercedes, Góngora heroico. Las «Soledades» y la tradición épica, Madrid, Centro de estudios Europa hispánica, 2012, pp. 304-307.

Castellanos, Juan de, Discurso del capitán Francisco Draque, ed. Ángel González Palencia, Madrid, Instituto Valencia de don Juan, 1921.

Covarrubias, Tesoro de la lengua castellana o española, ed. Ignacio Arellano y Rafael Zafra, Madrid, Iberoamericana, 2006.

Davis, Elizabeth, Myth and Identity in the Epic of Imperial Spain, Columbia/Londres, University of Missouri Press, 2000.

Ercilla, Alonso de La Araucana, ed. Isaías Lerner, Madrid, Cátedra, 2011.

Fernández, Mario, «Estudio preliminar», en Diego Arias Saavedra, Purén indómito, Concepción, Universidad de Concepción, 1984, pp. 92-108.

Fuchs, Barbara, Mimesis and Empire. The New World, Islam and European Identities, Cambridge, Cambridge University Press, 2001.

García Redondo, José María y Consuelo Varela, «Ecos literarios y memoria cartográfica del Famous Voyages de Francis Drake», Anuario de estudios americanos, 70, 2, 2013, pp. 441-478.

Hawkins, Richard, Observations of Sir Richard Hawkins in his voyage into the Sutth Sea, Londres, Hakluyt Society, 1847.

López Meraz, Óscar Fernando, «Demonología en la Nueva España: Fray Jerónimo de Mendieta y el Demonio», Revista complutense de historia de América, 34, 2008, pp. 131-155.

Mc Closkey, Jason, «Crossing the Line in the Sand: Francis Drake Imitating Ferdinand Magallanes in Juan Miramontes's Armas antárticas», Hispanic Review, 71, 2013, pp. 393-415.

Marrero-Fente, Raúl, «Piratería, historia y épica en la Elegía XIV de la Primera parte de Varones Ilustres de Indias (1589) de Juan de Castellanos», Revista de estudios colombianos, 55, 2014, pp. 4-11. 
Mazzocchi, Giuseppe, «Las Armas antárticas di Juan de Miramontes», en Intorno all'epica ispanica, ed. Paola Laskaris y Paolo Pintacuda, Como/Pavía, Ibis, 2016, pp. 121-142.

Mena, Juan de, Laberinto de Fortuna, ed. Luise Vasvari Fainberg, Madrid, Alhambra, 1982.

Mendieta, Jerónimo de, Historia eclesiástica indiana, México, Chávez Hayhoe, t. 2, 1945.

Miramontes, Juan de, Armas antárticas, ed. Paul Firbas, Lima, Pontificia Universidad Católica, 2006.

Murrin, Michael, History and warfare in Renaissance epic, Chicago, University of Chicago Press, 1994.

Nakashima, Roxana, «La circulation d'imprimés anglais: une fuite dans le système ibérique de contrôle des connaissances sur le Nouveau Monde», Nuevo Mundo Mundos Nuevos, Coloquios, 2013, en línea: <http://nuevomundo. revues.org/65687> [09/01/2016].

Nakashima, Roxana, «Contra los corsarios, al servicio de su Majestad. Expediciones inglesas por el Mar del Sur (1576-1594) en las informaciones de méritos y servicios de los vasallos del rey», en Felipe II y Almazarrón: la construcción de un imperio global. Vivir, defender y sentir la frontera, coord. María Martínez Alcalde, José Javier Ruiz Ibáñez, Murcia, Universidad de Murcia, 2014, vol. 1, pp. 311-329.

Navascués, Javier de, «Alarmas y sueños de codicia: los piratas en Argentina y conquista del Río de la Plata de Martín del Barco Centenera», Taller de Letras, NE3, 2013, pp. 179-190.

Nicolopulos, James, The Poetics of Empire in the Indies. Prophecy and Imitation in La Araucana and Os Lusiadas, Pittsburgh, The Pennsylvania State University Press, 2000.

Oña, Pedro de, Arauco domado, ed. Ornella Giannesin, Como/Pavía, Ibis, 2014.

Otero Lana, Enrique, Los corsarios españoles durante la decadencia de los Austrias, Madrid, Ministerio de Defensa, 1999.

Padrón, Ricardo, The Spacious Word. Cartography, Literatura and Empire in Early Modern Spain, Chicago, The Chicago University Press, 2004.

Peña, Enrique, «Apuntes biobibliográficos», en Martín del Barco Centenera, La Argentina. Poema histórico, Buenos Aires, Peuser, 1912, pp. XII-LII.

Saranyana, Josep-Ignasi y Ana de Zaballa, Joaquín de Fiore y América, Pamplona, Eunate, 1995.

Segas, Lise, «Le cycle de Drake: fortune littéraire d'une épopée transtatlantique au tournant du XVII siècle», Bulletin hispanique, 117-1 , 2015, pp. 231-258. 
Segas, Lise, "Cartagena de Indias en la obra de Juan de Castellanos: de la fundación a la destrucción de la ciudad», Aguaita, 24, 2012, pp. 28-47.

Segas, Lise, «El error y la errancia. El pirata "luterano" épico en las Indias», Cahiers de Framespa, 20, 2015, en línea: <https://framespa.revues.org/3543> [14/03/2016].

Suárez de Figueroa, Cristóbal, Hechos de don García Hurtado de Mendoza, ed. Enrique Suárez Figaredo, en línea: <http://users.ipfw.edu/jehle/CERVANTE/othertxts/Suarez_Figaredo_HechosCanete.pdf> [14/03/2016].

Usunáriz, Jesús María, «América en la política internacional española», en Discursos coloniales: texto y poder en la América hispana, ed. Pilar Latasa, Madrid, Iberoamericana, 2011, pp. 167-186.

Vega, Lope de, La Dragontea, ed. Antonio Sánchez Jiménez, Madrid, Cátedra, 2007. 
